\title{
Streetwise Politics: Feminist and Lesbian Grassroots Activism in Ljubljana
}

\author{
Tea Hvala
}

\section{Introduction: Feminist and Lesbian Counterpublics}

In 1990, the American political theorist Nancy Fraser argued for the necessity of theorizing non-liberal, non-bourgeois and competing public spheres that were excluded from Jürgen Habermas's influential theory on The Structural Transformation of the Public Sphere (1962). Her argument rested on the growing body of feminist and postcolonial revisionist historiographies which, among other things, demonstrated that members of subordinated social groups "repeatedly found it advantageous to constitute alternative publics" (Fraser 1990: 67). Fraser's main point was that "subaltern counterpublics" contested the exclusionary norms of the bourgeois public sphere by elaborating alternative styles of political behaviour and alternative norms of public speech. In these parallel discursive sites, subordinated people could "invent and circulate counterdiscourses, which in turn permitted them to formulate oppositional interpretations of their identities, interests and needs" (ibid.). Consequently they could enter the official public sphere on their own terms by representing themselves. The proliferation of counterpublics therefore lessens the chance of informal exclusion and leads towards greater democracy.

For Fraser, "participation means being able to speak 'in one's own voice', thereby simultaneously constructing and expressing one's cultural identity through idiom and style" (69). Counterpublics have the power to articulate an issue in their own way - or in dialogue with other counterpublics - and insist on it until it is recognized as an issue of general concern. Fraser mentions "domestic violence" or "date rape" as terms that have entered the list of general concerns and legislature because of feminist efforts that originally started in weak counterpublics that possessed only opinion-making power. ${ }^{1}$ In societies where legal equality does not guarantee actual equality, feminist and lesbian counterpublics continue to fulfil two functions: the

1 These examples confirm that Nancy Fraser was referring to feminist groups, rather than individual women who would fit Gayatri Spivak's definition of subalterns as "subjects of exploitation" who "cannot know and speak the text of female exploitation even if the absurdity of the nonrepresenting intellectual making space for her [them] to speak is achieved" (Spivak 1988: 84). Since my essay is concerned with feminist and lesbian activ- 
internal and the external. In Fraser's terms, counterpublics function internally as "spaces of withdrawal or regroupment" (68). The external function comes into play when members of feminist or lesbian counterpublics seek to convince society as a whole of the validity of their claims by challenging existing structures of authority through political activity and theoretical critique. In this sense, counterpublics function as "bases and training grounds for agitational activities directed towards wider publics" (ibid.).

Grassroots activism offers a variety of accessible communication and agitation tools to (mainly) young progressive feminists and lesbians who want to address wider publics. Since the concept of public sphere presupposes a plurality of perspectives among those who participate in it, the expression of conflicting views within (as well as between) political groups which strive for political recognition can be perceived as an advantage rather than a disadvantage. Knowing how vulnerable grassroots groups can be, I argue that some form of appeal to collective identity or solidarity has to prevail if a group wants to communicate with other counterpublics. In addition, there is always a disparity between the internal and external perception of specific counterpublics; between its self-understanding as a representative forum for a variety of (often conflictual) political identities, and the image of unity the group has to present to the public in order to be "taken seriously" - to be able to communicate with other (counter) publics. For Nancy Fraser, this communication is vital. She claims that the public orientation of oppositional spheres allows people's participation in more than one sphere, which makes both "intercultural and interpublic discussions possible" (70). Since the concept of counterpublics assumes an orientation towards wider publics, it - in the long run - also works against separatism: no matter how limited they are in their numbers or outreach, members of counterpublics see themselves as part of a potentially wider public. That is why counterpublics are not separatist enclaves by definition even if they might be "involuntarily enclaved" (67).

Due to historical and sociopolitical circumstances, discussed below, feminist and lesbian politics in Slovenia after 1991 have been marginalized to the extent that there is a great need for (grassroots) activism to defend already existing rights, demand new rights and most importantly, create new counterpublics where alternative norms of public speech can be developed. I applied Fraser's insistence on the necessity of proliferating forms of political expression to the tactical significance of what I call "streetwise politics" (local feminist and lesbian grassroots activism) because the institutionalized understanding of political participation and public matters of general concern in Slovenia continues to exclude such gender-related and sexuality-related issues as personal, private and apolitical. I am therefore not interested in "assigning abstract political value to particular techniques" (Felski 1989: 164), but in reviewing a selection of local feminist and lesbian street actions, street art and graffiti of the last two decades in order to see

ism in Slovenia, where counterpublic organizing is possible and indeed taking place, I have refrained from using the term "subaltern". 
how and why activists reacted to current political issues and/or addressed new ones. I am going to focus on the external function of local feminist and lesbian counterpublics - not because I would be merely interested in the immediately visible effects of their interventions in the official public sphere but because the length of this essay prevents me from examining their internal function. I have written about it elsewhere (Hvala 2010).

In what follows, I am going to review the historical and sociopolitical conditions that have contributed to the gradual disappearance of feminist and lesbian politics from the official public sphere in Slovenia. I am going to continue - and conclude - with the analysis of sporadic, fleeting, illegal and anonymous forms of political agitation in public space such as graffiti, stencils, posters, paste-ups and street performances that "take the space nobody offered" (Fajt and Velikonja 2006: 23).

\section{(In)visibility of Feminist and Lesbian Politics}

The participation of grassroots feminist and lesbian groups in Ljubljana's "new social movements" of the 1980s and their increasing public visibility at the end of that decade has been lessened by the 1991 disintegration of Yugoslavia, the subsequent wars in Croatia and Bosnia, nationalist and antifeminist historical revisionism, and finally, by the NGO-ization and the institutionalization of the relatively small movement. Whereas many feminist activists who protested against nationalism and war in 1991 were, especially in Croatia, demonized as "betrayers of the nation" and "witches", feminists in Slovenia were not ostracised to the same extent. Nevertheless, the movement was pacified as many groups shifted their focus from educational, agitational, and mobilizing activities to humanitarian, social and cultural work.

According to the feminists who helped shape the politics of "new feminism" of the 1980s, the feminist and (to a lesser extent) the lesbian movement of that period have "become part of everyday life" (Plahuta Simčič 2006: 15) after 1991 when former activists entered educational, cultural and social institutions, and - in humble proportions - parliamentary politics. While the simultaneous introduction of Gender Studies and feminist academic publishing has enabled the (re)production of feminist knowledge, it has - paradoxically, due to historic revisionism and the immediate discursive colonisation of Gender Studies programmes by British, American and French sources - produced a generation of highly educated women and men who are not aware of local feminist activist history and are unable to relate their academic knowledge about "women's issues" and "gender issues" to contemporary feminist and lesbian activism.

In the new, neoliberal setting, feminism in Slovenia was late to react to "the rise of the Church, the rise of the Right, the rise of hate speech" (Kuhar 2007: 11). It was also late to react to "an incredible wave of patriarchal and sexist views" (Plahuta Simčič 2006: 15) on one hand and "pop values, pop identities, with less and less immersion into things, apolitical standpoints" 
(Kuhar 2007: 11) on the other. While it is true that women have not lost any of the legal rights achieved in socialism, the reintroduction of "private patriarchy" (Burcar 2011), the increasingly precarious conditions on the labour market and repeated attacks on women's reproductive and sexual rights call for a strong opposition. Prominent feminist scholars like Svetlana Slapšak agree that "the situation is ripe for feminist activism" (Plahuta Simčič 2006: 15). In 2006, when the Ministry of Labour, Family and Social Affairs intended to limit abortion rights, graffiti from 1991 (the year when abortion rights were threatened as well) appeared with renewed urgency. "Women against nation - for abortion rights" (Photo 1) they called, signed by the feminist symbol and a clenched fist. More graffiti from 2006 cynically remarked that in Slovenia, "A foetus has more rights than a woman".

\section{Photo 1: "Women against nation - for abortion rights"}

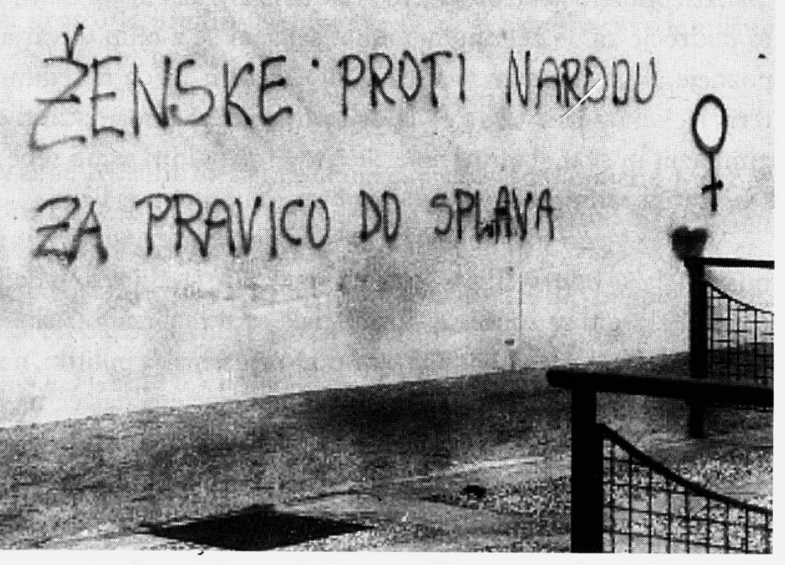

Photo by Barbara Berce, 1991. This graffiti reappeared near the (old)

Pediatric Clinic in Ljubljana in 2006.

Since 1993, when a large alliance of political groups and artists occupied the former military base on Metelkova Street in Ljubljana, most of the grassroots feminist and lesbian groups have been based there, in the Autonomous Cultural Centre (ACC) Metelkova mesto. Because feminist and lesbian counterpublics in Metelkova were shaped by so many individuals, groups and events, and because these groups collaborated, disbanded and later joined forces on different political grounds, their knowledge production has to be theorized as a discontinuous and site-specific practice, defined by a variety of non-dominant and non-hegemonic views. Today, collaborations between academic, non-governmental and grassroots ini- 
tiatives do exist; however these groups cooperate only in response to particularly dangerous threats or cases of discrimination and usually disband when the goals of the struggle have been achieved. This defensive position is one of the reasons for their political invisibility.

The temporary and provisional nature of cooperative actions in Ljubljana reflects other problems that are specific to feminisms from postsocialist countries and only partly coincide with the problems of Western feminisms: the reluctance to identify and be recognized as feminists due to the general stigmatization of feminism as a separatist and misandrist ideology; the depoliticized attitude towards a number of issues including class differences within the traditional (unified) political subject of women; and the lack of solidarity between feminists and other social movements, their potential allies. I believe those are the main reasons why a feminist counterpublic with "the potential to build alliances and collaborations across divisive boundaries" (Mohanty 1991: 196) is, at this stage, still very vulnerable and loose. Nevertheless, the existing alliances are important agents of both continuity and change within the fragmented feminist map of Ljubljana; they can serve as a platform for the development of stronger feminist and lesbian movement.

It is interesting to note that in the last twenty years, lesbian activism has been more visible than feminist activism. There is a tendency to explain this disparity by the greater stigmatization of LGBTI people who are, supposedly because of their greater exposure to verbal and physical violence, more committed to activism. A more reasonable answer relates to the fact that "the state does not need professional lesbians and gays" (Kuhar 2007: 11). That is how Suzana Tratnik, lesbian activist and award-winning fiction writer, replied to the question of why the lesbian movement, unlike feminism, was not institutionalized in the 1990s. It might also be the reason why the new generation of politically engaged lesbians in the 1990s and 2000s regularly frequented the "streetwise school" of activism and wrote its own "graffiti textbook". Lesbian activist and theorist Nataša Velikonja wrote: "In the late 1990s, when the level of homophobia in Slovenia rose and the educative tools against intolerance were entirely insufficient, a library wall in Maribor was sprayed with the slogan 'Where are all the lesbian books?'” (Velikonja 2004: 125).

In the next section, I am going to review the metaphorical textbook of grassroots activism that has been - and continues to be - "written" by and for young progressive feminists and lesbians who are forming their political identity through practice. I will focus on several examples that represent some of the most frequent themes and tactical approaches, used in streetwise politics. However, due to the methodological difficulties related to the research of anonymous actions (such as the lack of sources), my essay should not be read as the only possible history of feminist and lesbian grassroots activism in Ljubljana. 


\section{Feminist and Lesbian Grassroots Activism in Ljubljana}

Graffiti and public interventions are sporadic, fleeting, mostly anonymous and illegal forms of political agitation using artistic means. Especially for young feminist and lesbian activists, they represent the most accessible and visible medium of resistance. The case of feminist graffiti from 1995 ("Goddammit, Ivan! Make that damn coffee yourself! - Mother Francka") indicates that these actions can have very provocative effects.

"Ivan's graffiti" was written on 25 November 1995 as part of activities organized for the International Days for the Elimination of Violence against Women by groups from the (now defunct) Women's Centre in Metelkova: Kasandra, Women's Counselling Service, Modra and Prenner Club. The alliance carried out an impressive action with slogans addressing domestic violence, rape, incest and several other issues. From a feminist point of view, the graffiti parodying Ivan Cankar's Skodelica kave (1920), ${ }^{2}$ a short story that had been "nationalized" to serve the Slovenian literary establishment long before 1991, was protesting against the gendered division of labour. Gregor Tomc, a prominent sociologist specialized in subcultures, responded with an article published in the largest daily in Slovenia. He claimed that graffiti written by "Ljubljana's Amazons" dealt with obsolete issues, since "contemporary Slovenian family has overcome the traditional division of labour a long time ago" (Tomc 1996: 39), thus referring to the indeed obsolete state-socialist views on feminism as a superfluous ideology. Similarly, graffiti that addressed women's sexual rights were accused of animosity and separatism while lesbian graffiti like "No more fear - Thelma and Louise", "No more shame-Mojca and Metka" or "Lesbians for peace - Peace to lesbians" were denied both peace and equality by his statement that "a heterosexual relationship and homosexual sexuality, after all, cannot be equal" (ibid.). Gregor Tomc tried to discredit the activists with antifeminist views that continue to dominate the public sphere in Slovenia. Of course, from a feminist and lesbian point of view, the article discredited its author. ${ }^{3}$

In 1997, Lesbo magazine documented a series of lesbian graffiti written on the river banks of Ljubljanica. Graffiti such as "Eva + Adama" and "My grandfather is bisexual" ridiculed compulsory heterosexuality; others like "Sorry mum, no grandchildren" kept the same humorous spirit as the action carried out in the night before Independence Day (25 June) when activists "appropriated" the national holiday by postering the center of town with Lesbo covers. Ten years later, lesbian graffiti continue to be more visible than

2 Ivan Cankar's autobiographical short story Cup of Coffee [my translation] is about young Ivan who visits his poor mother and asks her for a cup of coffee, knowing that she cannot even afford to buy bread. To his surprise, his mother manages to find and prepare coffee for him but he refuses to drink it and tells her to stop bothering him. The narrator deeply regrets young Ivan's reaction and speaks of his lasting feeling of guilt.

3 "Ivan's graffiti" was also printed on promotional postcards of the Women's Group within Združena lista, a coalition that later restructured into a centre-left political party. Also, journalist Agata Tomažič used it in her 2004 critique of the nationalist appropriation and ideological exploitation of Ivan Cankar's literature in Slovene schools. 
feminist ones. Slogans like "Homophobes are human, too" and "Step out of the heterosexual matrix" are among the few that directly address heterosexuals. The idea that it is possible to "step out of the matrix" has received an interestingly utopian (or queer) answer in January 2008 when the order of construction site fences on which it was originally sprayed was changed so that the new constellation read "trix ual ma heterosex Step out".

In the new millennium, several feminist actions were inspired by UZI (Urad za intervencije or Bureau for Interventions), an informal network of local groups, founded after the protests against the World Trade Organization meeting in Seattle in 1999. For example, "in Interspar [shop], a group of female activists 'advertised' Heidersil; a new washing powder that cleans historic stains and contains 'adolfils'" (Zadnikar 2004: 15). On 8 March 2001, the Women's Section of UZI temporarily squatted in two cosmetics and women's apparel shops in Ljubljana in order to address the commercialization of International Women's Day and the privatization of public space. When the dancing activists were asked to leave, they continued the action on public grounds (outside the shop's entrance). On the same day, Nada Hass, an improvised all-female activist choir, performed at Klub Gromka in ACC Metelkova mesto. Dressed up as cleaners and housekeepers, they sang: "Let's set things straight with our past, let's wipe away the borders, let's make our relationships work and wipe away the violence" (Ozmec 2001: 14). (Photo 2)

Photo 2: Spontaneous street action in the centre of Ljubljana during 9th Rdeče zore festival

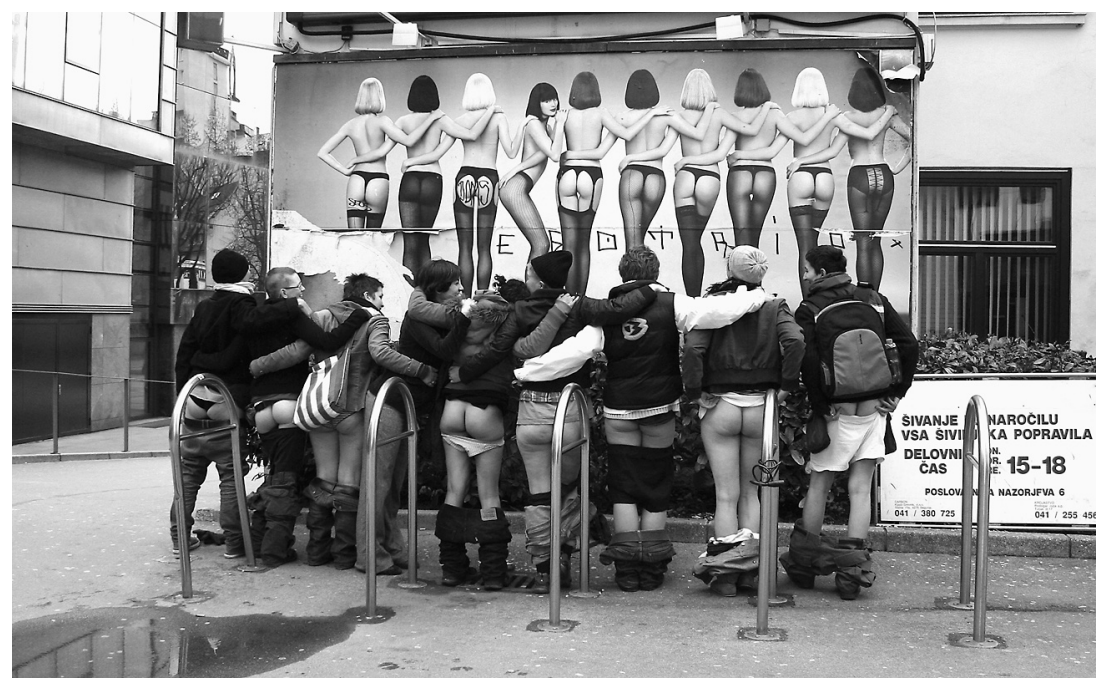

Photo by Rüzgar, 9 March 2008.

In Slovenia, the country where lesbians and gays are still denied the legal rights provided by the institution of marriage ("Registration = discrimination" sums up the issue in graffiti on Roška street), reproductive rights have 
been discussed primarily in relation to heterosexual women. However, in 2000 when the right-wing government attempted to implement legislation that would make artificial insemination available only to heterosexual couples who are married or cohabiting, this serious violation of women's reproductive choices faced severe opposition from a wide array of feminist, lesbian and other progressive groups. Four years later, on 8 March 2005, an anonymous letter entitled Do you remember March 8th? claimed that the new governmental program for positive demographic growth used hate speech and discriminatory measures. The letter was handed out by a small activist group that staged a burlesque portrayal of patriarchal family roles in Park Zvezda and managed to ridicule the (former) Minister of Labour, Family and Social Affairs Janez Drobnič personally by calling itself The Janez Drobnič Folklore Group.

On 15 November 2006, the same minister proposed a "fertility raising strategy" which, among many other discriminatory measures, tried to limit access to abortion. The strategy proposed a 400 euro fee for certain procedures, thus ensuring that abortion would become inaccessible for a large number of poor women and girls. The strategy, like the successfully opposed proposition from 1991, was to instrumentalize women for the state's "nation-building" goals. Furthermore, the new legislation used Catholic discourse that equates the beginning of life with conception. Feminists responded with graffiti declaring "Let's abort Drobnič!", "I'd rather be a testtube baby than Drobnič's child" and a slogan which connected the discriminatory proposal about artificial insemination from 2000 with the same type of demographic policy by sarcastically offering "the perfect solution": "To raise fertility - inseminate single women and lesbians". On 17 November, Feminist Initiative in Support of Abortion Rights entered ministry bureaus early in the morning and met the employees with statements objecting to the proposed strategy. The activists used posters and banners to surround the bureaus and expose them to the public as violators of women's rights. The slogans ("Women = birth machines", "Defend abortion rights now - tomorrow it is going to be too late", "Yesterday migrants and Erased citizens, today Roma people and women; who is next?") connected discriminatory policies against women with institutionalized violence against sexual and ethnic minorities.

On the eve of large trade union demonstrations of 17 November 2007, Ljubljana's streets were sprayed with several different examples of feminist graffiti. Older graffiti ("Fuck better wages, I don't even have one - Housewife", "New! Housework workshops for men", "Boys, who's gonna do the dishes?") were accompanied by a series of new protests. Perhaps the most memorable was the stencil of a young woman with a clenched fist, shouting "Because we are not a commodity!" (photo 3) An ambiguous stencil designed to look like a construction site traffic sign (the official sign "Workers on the street" includes an image of a male worker with a shovel in his hands) claimed "Female workers on the street -17.11." and replaced the male worker with an image of three women and a small girl holding hands. It could be read in several ways: as a call for joining the trade union demonstrations, as a comment on 
the growing rates of unemployment among women and the discrimination of mothers on the labour market or as an indirect reminder that sex work is an illegal and dangerous yet possible source of income for impoverished women. The workers' demonstrations were supported by Avtonomna tribuna, a students' alliance which included an explicitly feminist initiative (The Feminist Initiative for Social Rights) and a lesbian-feminist group called The Lesbian Insurrection. ${ }^{4}$ Their members carried anarchofeminist flags, cynical banners like "I am a woman, therefore I work for free" and the classic slogan "We are lesbians and we are everywhere".

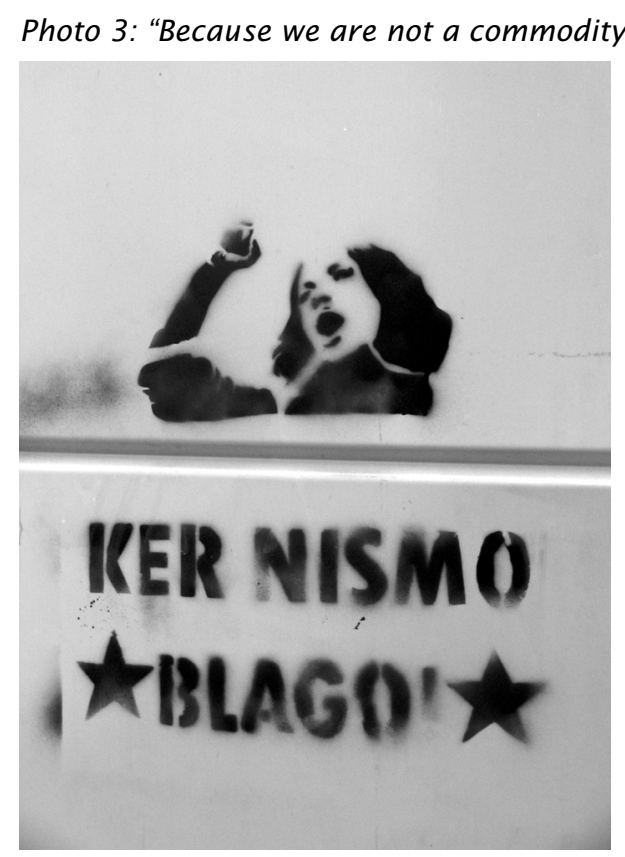

Photo by Tea Hvala, 17 November 2007, the eve of large trade union protests in Ljubljana.

Very little graffiti in Ljubljana concerned sex work (with the exception of “Prostitutes of the world, unite!"). A few days before 8 March 2007, a series of posters appeared that problematized the relation between economy and the regulation of sexuality. Troubling questions like "Do money and love exclude each other?" were written in the headers of large blank sheets of paper, intended for comments of people who passed by. Somebody replied: "Not really". The question "Is marriage an institution of legal prostitution?" was reformulated in barely legible handwriting as "Legal prostitution is the institution of marriage. Complicated, huh?" while somebody

4 Vstaja Lezbosov or The Lesbian Insurrection was formed after 10 October 2007, when two lesbians were forced to leave Orto bar, a rock bar in Ljubljana, because of "explicitly showing their lesbian identity" (Tratnik 2007: 14) by kissing in public. 
else simply confessed that s/he "Wouldn't know". Comments to the question "What do you expect from sex after marriage?" were hilarious: "Nothing, I' m already married" and "Sex with a relative". The poster series also included questions like "What do artists and sex workers have in common?" and "Are sex workers the last street fighters?". The postering action was organised by a Viennese feminist art collective which was invited to Ljubljana by the International Feminist and Queer Festival Rdeče zore as part of the Sex, Work and Society art exhibition in Alkatraz Gallery.

\section{Photo 4: "Street of Feminist Movements"}

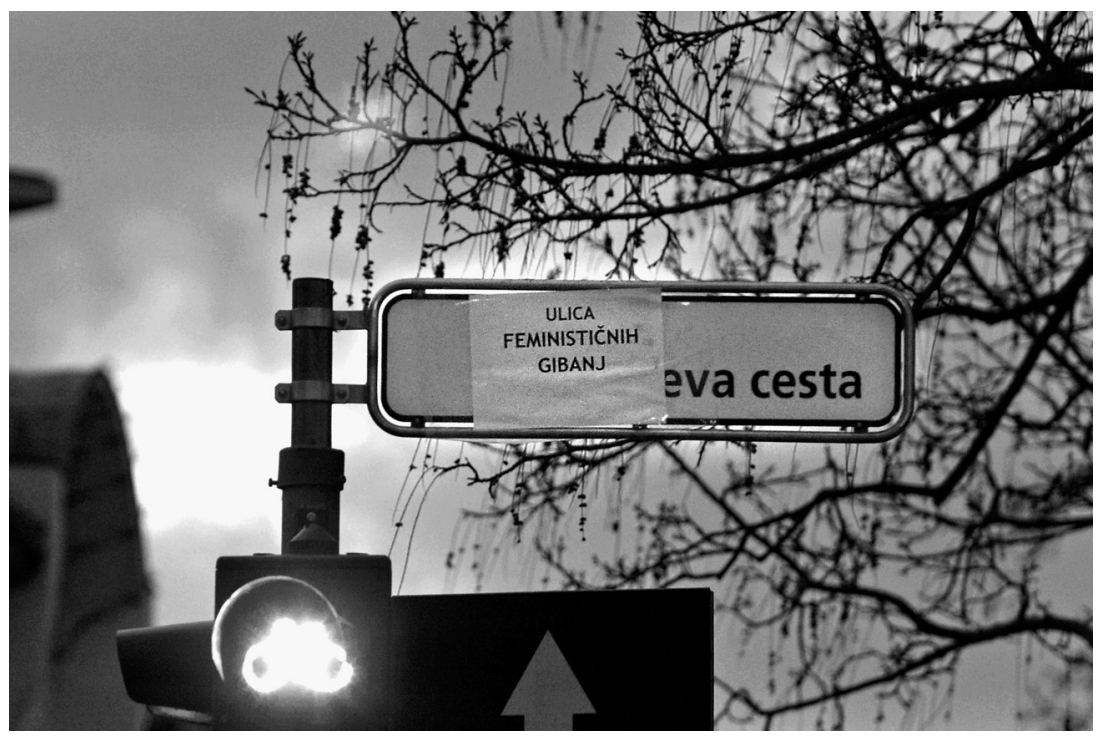

Photo by Nada Žgank, 2007.

In the night of 8-9 March 2007, several feminist activist groups renamed around fifty streets in Ljubljana. Like the street-renaming actions in Zagreb (2006), Sarajevo (2006) and Kutina (2007), the action in Ljubljana was based on the statistical fact that the majority of streets are named after men and the feminist fact that women need to contest versions of history that exclude them. New street names paid homage to The International Women's Day, Simone de Beauvoir, local and international women artists, female pop icons, women political organizers and activists, important events from feminist history, fictional female characters, etc. (Photo 4) In November 2007, a similar action was carried out in Maribor where The Lesbian Insurrection group introduced the Square of Lesbian Revolution (including house number 69), the Lesbian Path and the Road to the Lesbian. These signs were left on display for several weeks. However, Path to the Lesbian Peak and Square of Lesbian Brigades (Photo 5) disappeared immediately: probably because they renamed the official address of the Roman Catholic Diocese and Archdiocese in Maribor. 


\section{Photo 5: "Square of Lesbian Brigades" at the seat of the Roman Catholic Archdiocese in Maribor}

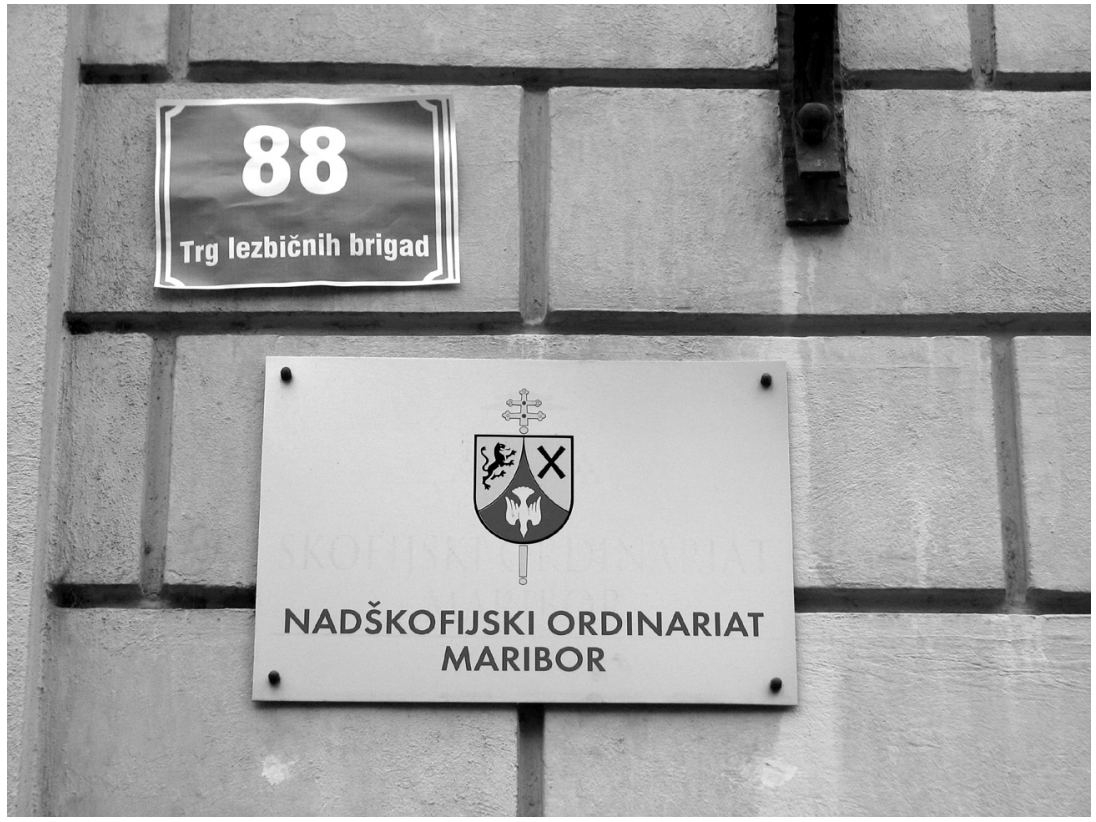

Photo by Mojca Rugelj, 2007.

In the night of 8 March 2012, two anonymous actions took place in the centre of Ljubljana. The first included graffiti and stickers with slogans such as "Proud Feminist" and "Up with Feminism!"; the other action was strategically placed in front of the local Museum of Contemporary History, which hosted an exhibition about Slovene women's struggles for emancipation between 1848 and 1945. The activists spray-painted the tank in front of the museum a pink colour, ridiculing the militarist symbol of Slovene independence and commenting on the fact that an exhibition dedicated to feminist history was symbolically threatened by a tank from the tenday war in 1991 (and the implied historical revisionism). The director of the museum failed to see or publicly mention the action's connection to the exhibition, to International Women's Day or to LGBTI couples whose right to adopt a child was rejected in a referendum on 25 March 2012. The director said: "Since we don't know how we are going to restore the tank, we thank the guerillas or the vandals for at least choosing a colour that matches the museum's façade" (Svenšek 2012). The third feminist action on 8 March 2012 was organised by the international arts collective Bring In Take Out - Living Archive, who co-organised the visual arts programme of the $13^{\text {th }}$ Rdeče zore festival. Its members joined the $15 \mathrm{O}$ (15 October or Occupy!) demonstrations against austerity measures and blocked the entrance to several banks in the centre of Ljubljana. The feminist art collective protested against "all forms of social repression and economic exploita- 
tion" (Crvena 2012) and paid homage to the women textile workers' strike in Lawrence, Massachusetts, on 8 March 1912 by chanting "We want bread, and roses too."

\section{Conclusion}

The grassroots actions discussed in this essay by no means represent the entire thematic and tactical scope of feminist and lesbian streetwise politics in Ljubljana. However, I tried to select examples that represent the most frequently addressed issues and the most common tactics. To summarize: in the past twenty years, feminist and lesbian activists criticized the gendered division of labour (women's unpaid reproductive labour vs. men's paid productive work), the growing rates of unemployment among (older) women, discrimination of mothers on the labour market, precarious labour conditions in general, double measures regarding the (lack of) regulation of sex work, the instrumentalization of women's reproductive and sexual freedom by the state, domestic violence, rape, incest, institutionalized violence against sexual and ethnic minorities, compulsory heterosexuality, legal discrimination of same-sex couples, conservative revisions of history, commodification of International Women's Day and the privatization of public space. They advocated pacifism, lesbian visibility, women's sexual freedom, reproductive rights of LGBTI people and single women, the destigmatization of sex work and the general visibility of feminist politics. In doing so, the activists have employed the following tactics and tools: graffiti, stencils, posters, paste-ups, demonstrations and street art (performance, theatre, singing).

I interpreted feminist and lesbian grassroots actions in Ljubljana as sporadic, fleeting and mostly anonymous interventions in the public sphere and in the sphere of institutionalized knowledge (re)production. I argued that they represent an important chapter in the metaphorical textbook "written" by and for young progressive feminists and lesbians who are forming their political identity through practice. Since most of these actions were illegal, the activists had to learn to cope with the stress of (probable) harassment by their political opponents or the police. They were strengthened in the process. The activists were additionally strengthened by the chance to articulate their own political identity, needs and demands in ways that suited them. As such, grassroots activism can be theorized as one of the communication tools available to young activists who want to develop their own counterpublics and alternative norms of public speech. Finally, I argued for the necessity of expanding the notions of political and public beyond those prevalent in the official public sphere in Slovenia. My essay can be therefore read as an internal critique of the latter and as a contribution to the diversification of (counter)public feminist and lesbian discourses. As the actions described in this paper suggest, one of the places where these discourses can be tested publicly is the streets. 


\section{References}

Burcar, L., 2011. What is Left of the Feminist Left? [online]. Available at: $<$ http://bringintakeout.wordpress.com/video-booth/audio-interviews/> [Accessed 27 October 2011].

Crvena, 2012. We want Bread, and Roses Too [online]. Available at: <http:// bringintakeout.wordpress.com/2012/03/12/we-want-bread-and-rosestoo/> [Accessed 15 March 2012].

Fajt, M. and Velikonja, M., 2006. Ulice govorijo/Streets are Saying Things. Časopis za kritiko znanosti 223, pp. 22-29.

Fraser, N., 1990. Rethinking the Public Sphere: A Contribution to the Critique of Actually Existing Democracy. Social Text 25-26, pp. 56-80.

Hvala, T., 2010. The Red Dawns Festival as a Feminist-Queer Counterpublic. Monitor ISH (1/XII), pp. 7-107.

Kuhar, R., 2007. Prečuta noč za lezbični manifest. Intervju z Natašo Sukič in Suzano Tratnik. Narobe 4, pp. 9-12.

Mohanty, C. T., 1991. Cartographies of Struggle: Third World Women and the Politics of Feminism. In: P. Essed, ed., 1991. Race Critical Theories: Text and Context. Oxford: Blackwell Publishing, pp. 195-219.

Ozmec, S., 2001. Osmi marec: dan, ko se pretvarjamo, da je vse v redu. Mladina [online], 19 March. Available at: <http://www.mladina.si/ tednik/200111/clanek/m-osmi/> [Accessed 27 October 2011].

Plahuta Simčič, V., 2006. Ne smemo se slepiti, patriarhat je povsod! Delo (48/74), p. 15.

Svenšek, A., 2012. Rožnati tank pred muzejem: vsak ima svojo interpretacijo akcije. Multimedijski center RTV SLO [online], 8 March. Available at: <http://www.rtvslo.si/slovenija/roznati-tank-pred-muzejem-vsakima-svojo-interpretacijo-akcije/278467> [Accessed 20 March 2012].

Tomc, G., 1996. Je ženska brez moškega kot riba brez bicikla? Delo - Sobotna priloga (38/28), p. 39.

Tratnik, S. 2007. Ne vstopaj s svojimi sendviči! Narobe 4, pp. 14-15.

Velikonja, N., 2004. Grafiti: poulično revolucionarno branje. In: L. Stepančič and B. Zrinski, eds. Grafitarji/Graffitists. Ljubljana: MGLC, pp. 124-130.

Zadnikar, D., 2004. Kronika radostnega uporništva. In: J. Holloway, ed. Spreminjamo svet brez boja za oblast: pomen revolucije danes. Ljubljana: Študentska založba, pp. 201-225. 